\title{
A LONGITUDINAL ANALYSIS OF THE INDONESIAN PRODUCTION SHARING CONTRACTS (PSC): THE QUESTION OF ECONOMIC ACCOUNTABILITY
}

\author{
Parulian Sihotang ${ }^{1}$
}

\begin{abstract}
The article objective is to describe a longitudinal analysis of the Indonesian Production Sharing Contracts (PSC). Article presents the history of petroleum contractual agreements in Indonesia, selected indicators to evaluate PSCs performance, the statistical techniques used to analyze the data, statistical results, operational indicators, discussion of results and linkage to concept of accountability. The conclusion is the longitudinal study on the PSCs performance over the last 30 years have indicated that the current structure of the agreements seemed to have failed in supporting the dynamic contractual accountability between the host country and the FOCs. The PSCs lacked the capability to promote both host country and FOCs' interests in a fair and reasonable way.
\end{abstract}

Keywords: Production Sharing Contracts (PSC), contractual accountability

\begin{abstract}
ABSTRAK
Penulisan artikel bertujuan untuk mendeskripsikan analisis longitudinal Production Sharing Contracts (PSC). Dalam artikel ini dibahas sejarah perjanjian kontrak minyak di Indonesia, indikator terpilih untuk mengevaluasi Production Sharing Contracts (PSC), teknik statistik yang digunakan untuk menganalisis data, hasil statistik, indikator operasional, diskusi hasil dan kaitan konsep akuntabilitas. Simpulannya, studi longitudinal tentang Production Sharing Contracts (PSC) lebih dari 30 tahun telah mengindikasikan bahwa struktur perjanjiannya telah gagal dalam mendukung kontrak akuntabilitas dinamis antara negara tuan rumah dan kepentingan FOCs' yang adil dan masuk akal.
\end{abstract}

Kata kunci: Production Sharing Contracts (PSC), akuntabilitas kontraktual

\footnotetext{
${ }^{1}$ Staf Pengajar Institut Pendidikan Auditor Internal Indonesia \& Jurusan Manajemen, Fakultas Ekonomi, UBiNus, Jakarta
} 


\section{INTRODUCTION}

This article analyzes the performance of the Indonesian PSCs since their inception in 1967 in order to shed some light on (1) how well-fitted the Indonesian PSCs, in their current structure and substance, have been in supporting the dynamic contractual accountability between the host country and the FOCs for the last 30 years in order to promote each party's interests in a fair and reasonable way; (2) the role of the Indonesian PSCs in developing the up-stream activities in Indonesia over the last 30 years; (3) how changes in the terms and conditions of the Indonesian PSCs have led to changes in the up-stream sector's performance; and (4) whether the changes in PSCs terms and conditions have done more good than harm for developing an accountable and transparent government-led management of the Indonesian petroleum industry.

\section{The History of Petroleum Contractual Agreements in Indonesia}

Rochmat (1981) revealed that the historical development of contractual arrangements in the oil and gas sector in Indonesia can be divided into three eras: the era of concessionary contract, that of contract of work, and that of production sharing contracts.

\section{Concessionary Contracts}

Johnston (1994) argued that: "Concessionary systems, as the term implies, allow private ownership of mineral resources". Under these systems the government transfers the title of the minerals to a company if they are produced. The company is then subject to payment of royalties and taxes.

Prior to 1960, exploration and exploitation in the field of mining including oil and gas in Indonesia were governed by the rules of law as stipulated in the Indies Mining Law of 1899. Under this Law of 1899, petroleum exploration was based on concessions in which the colonial government granted petroleum ownership rights to foreign companies in return for (surface) tax and royalty. The concession, in effect, surrenders part of a nation's sovereignty to concessionaire (Machmud, 2000). Under this agreement, the government did not interfere with the domestic affairs of the concessionaire and acted merely as a tax collector.

\section{Contract of Work (CoW)}

The main characteristics of these Contracts of Works included as follows.

(1) A requirement for minimum exploration commitment.

(2) A mandatory relinquishment of 25 per cent of the area after five years of exploration and another 25 per cent after 10 years.

(3) The requirement that the title of oil passed to the foreign company at the point of sale.

(4) A 60 per cent/40 per cent profit split in favour of Indonesian government after cost recovery.

(5) A signature and production bonus of $\$ 5$ million, respectively, for new areas.

(6) The foreign oil companies were to act as the exclusive sales agent to market the oil but the National Oil Company reserved the right to elect to take 20 per cent of the aggregate production in kind.

(7) The title to equipment was to belong to the foreign company until fully depreciated. 
(8) The foreign companies agreed to supply the Indonesian domestic market with crude oil and refined products at cost plus fixed fee.

(9) The status of the foreign oil company was as Contractor to the National Oil Company (NOC), but the foreign company still retained the management control of the petroleum operation.

The CoW is based on the principle that sovereignty over natural resources is vested in the state until the point of sale. This type of agreement also obliged the companies to relinquish their existing concessions to the government and turned them into contractors for the state companies.

\section{Production Sharing Contracts (PSCs)}

The production-sharing agreement was devised by Dr. Ibnu Sutowo (Rochmat, 1981; Bee,1982; Johnston, 1994). There are several differences between the CoW and PSC. If the CoW was signed by the government, the PSCs were signed by the National Oil Company. PSCs are not subject to ratification by the parliament but must be approved by the president of Indonesia. The National Oil Company, is therefore, active in all fields and phases of the operations.

\section{Characteristics of PSCs}

Indonesia is believed to be the first country to apply production sharing to petroleum operations (Barrow, 1993). The first production sharing agreement was signed in 1966 with International Indonesian American Petroleum Company (IIAPCO) a small independent company compared to the big former concession holders in Indonesia. The basic structure of the Indonesian PSCs reflects the following features.

(1) Management is vested in the National Oil Company, Pertamina. Contractors, mainly foreign oil companies, are the operators who are responsible to Pertamina for operations in accordance with agreed Work Programs and Budget.

(2) The contractor provides all financial and technical assistance for petroleum operations, and carries the risk of operating costs.

(3) The Contractor prepares a work program and budget of operating costs annually to be agreed with Pertamina.

(4) All equipment purchased by the contractor becomes the property of Pertamina when landed in Indonesia, although leased equipment is exempt.

(5) Pertamina has the title to all data obtained from the operations.

(6) The contractor pays Indonesian taxes on income. Pertamina reimburses the contractor for other taxes paid in conducting operations.

(7) The contractor is to supply Indonesia's domestic requirement for crude oil, called the Domestic Market Obligation (DMO).

\section{PSCs Generations}

Barrow (1993) argued that Indonesian PSCs have evolved over three generations; PSCs generation-1 lasted for 10 years from 1966 to 1976, PSCs generation-2 lasted for 11 years up to 1987, while those of generation-3 lasted from 1988 to 1999. 
The first generation PSC was introduced in 1966. The principal features of the 1966 to 1976 PSCs include bellows.

a. Pertamina had the final management by approving Work Program,Budget and Plan of Development.

b. All equipment bought by the contractor and imported into Indonesia automatically became the property of Pertamina. However, the contractor had the first right of use of assets as long as they were required for operations.

c. Contractors having more than one working area in Indonesia could not consolidate financial results for calculating their obligation to the Government. This ring fence has continued in subsequent generations of the PSCs.

d. Under the simple first generation of PSCs, cost recovery was limited to $40 \%$ of production. The remaining $60 \%$ of production were shared between the Government (65\%) and the contractor (35\%). The 35\% was a clean share, or an after-tax income for the contractor, as the National Oil Company assumed the tax obligation. However, above the production level of 75, 000 barrel of oil per day (BOPD), the formula became $67.5 \% / 32.5 \%$ in favour of the Government.

e. Contractors were obliged to deliver oil to the domestic market up to a maximum of $25 \%$ of their 35\% share of total production, for which they received a fee of $\$ 0.20$ per barrel.

The PSC was amended in early 1974 owing to the rapid oil price increase in 1973. The balance between the actual price and the base price, multiplied by the contractor's equity share, was split 85 to 15 in favour of the Government. In 1975 a US tax ruling disallowed tax credits for corporate taxes paid in Indonesia by the contractors under PSCs. Consequently, negotiations to amend the PSCs took place in 1976, and the second generation was introduced.

\section{Second Generation: 1976 to 1988}

Under the second generation, PSCs the basic principles remained the same but cost was now calculated on the accepted accounting principles without a $40 \%$ ceiling. In other words, there was a $100 \%$ cost recovery. The remaining revenue was split 85 to 15 in favour of the Government. The idea of depreciation and amortization was introduced in determining total cost recoveries. Under the new scheme, cost recovery consists of all current year non-capital cost, the amortization of carried-forward non-capital costs (The carried-forward non-capital costs include pre-1976 Contractors' un-recovered expenditure carried forward to subsequent years) and the depreciation of capital costs. The capital costs were depreciated using DDB (double declining balance) at different percentages depending on the capital asset groupings/classifications, while the carriedforward non-capital costs were depreciated using SLD (Straight Line Declining) over the remaining useful life.

Determining cost recovery based on accepted accounting principles without ceiling created complications when oil prices started to fall in the early 1980's; a new field, with high costs and a small reserve, might not provide income to the Government during the entire lifetime. Therefore, to protect the Government's income, the National Oil Company created a new rule, the 'Declaration of Commerciality', in which a new field could only be declared 'commercial' for development if there was at least $49 \%$ of the cash flow for the Government. Contractors were generally unhappy with this requirement due to the fact that such declaration was unilaterally 
determined under the authority of Pertamina. If Pertamina declared that a field was not commercial, it meant Contractors could not recover all their operating expenditures. This new rule contained many loopholes for collusion and corruption that added more inefficiencies to the industry (Oon, 1986; Barnes, 1995). Due to these weaknesses, the third generation of PSCs was introduced to help solving them.

\section{Third Generation: 1988 to 1999}

In 1988, the Government issued some incentives to enhance oil exploration activities, creating the 'third generation' PSCs. There were some basic changes to this generation compared to the previous generation. For special conditions such as for pre-tertiary layers in frontier areas, the $85 \%$ minimum Government Take was reduced to $75 \%$. The take for small fields in conventional areas was reduced to $80 \%$ and to $75 \%$ in frontier areas.

The DMO fee, which had been $\$ 0.20$ per barrel in previous generations, was increased to $10 \%$ of export price, and in 1992 it was increased again to $15 \%$ of export price. However, for the first five years full export price was given. At the same time, based on the 1984 tax law, Contractor's tax rate was reduced from 56 to 48 per cent thereby resulting in a reduction of the 'gross up' in kind received by the Contractors (from 34.09 to 28.85 per cent).

During this generation, as a 'floor' for Government revenue and to eliminate the 'commerciality' issue, the 'First Tranche Petroleum' (FTP) concept was introduced in 1988. Under this concept, the first 20 per cent of production was subject to production sharing before cost recovery. This 20 per cent FTP was split between the Government and the Contractor, based on the prevailing PSC arrangement.

In 1988, 1989, 1992, 1993 and 1994, the Government issued a series of exploration incentives packages designed to encourage new exploration in high-risk areas - especially in the eastern part of Indonesia. The Government issued improved contract terms, first on 31 August 1988, then on 22 February 1989 and later on 31 August 1992. For example, in the 1988 package the investment credit became $110 \%$ for oil and 55\% for gas for new PSCs, both standard and frontier/deepwater, while in the 1989 package, crude production from pre-tertiary reservoir rock was divided on the basis of incremental sliding scale (Crude productions up to 50,000 b/d are divided 80/20, from 50,000 - 150,000 b/d using 85/15 and over 150,000 b/d using 90/10 in favour of government).

The 1992 incentives contained improvements to existing contract terms which were designed to increase exploration activities particularly in high-risk frontier areas. For example, there was a $125 \%$ incentive credit for exploration in water depth in excess of 1,500 meters. The 1993/1994 incentive packages were aimed at stimulating exploration in the eastern part of Indonesia. For example, the FTP was reduced from $20 \%$ to $15 \%$.

\section{The New Oil and Gas Law}

In November 2001, the Indonesian parliament finally passed a new oil and gas law to replace the two previous laws (Law No.44/1960 and No.8/1971) despite a chorus of criticism against it from a number of special interest groups such as NOC, local authorities and environmental groups (Jakarta Post, 2001). The new law is aimed at liberalizing the oil and gas sector by scrapping a 30-year monopoly held by the National Oil Company, Pertamina. 
The bill promises a fundamental change in the governance of Indonesian's petroleum industry by establishing two new government agencies: implementing and regulatory body. The implementing body is assigned to regulate up-stream sector and take over Pertamina's role in dealing with foreign oil companies, while the independent regulatory body will manage domestic fuel supplies and distribution. The law states that Pertamina must become a limited liability company within two years, thus forcing it to compete with domestic and international companies. Under the new law, the investor may enter a cooperation contract, not necessarily limited to a production sharing agreement, as long as such a contract is beneficial for the country.

\section{Selected Indicators to evaluate PSCs Performance}

Two indicators were selected in order to evaluate the degree of up-stream activities and performance under the Indonesian PSCs: financial and operational indicators. Financial indicators include government share (both in relative and absolute terms), contractor share (both in relative and absolute terms), cost recoveries, contractors' profits and total exploration expenditure. Operational indicators include seismic activities, exploratory wells completed, total proven and probable reserve, total crude production and the total PSCs approved and signed by the government.

\section{Financial Indicators}

In this study, financial indicators include government share and contractor share which consists of contractor profit and cost recoveries as defined in the literature (Johnston 1994;Barrow, 1993; Bindemann, 1999). Government share, used interchangeably with government take, includes all revenues for the government under the PSCs such as royalties, bonuses, FTP, tax, profit oil or revenue, but excludes DMO. Cost recoveries consist of all non-capital expenditure and a portion of capital expenditure claimed by Contractors under the accounting rules and procedures stipulated in Exhibit C of the PSCs, while contractor profit means net of tax profit oil distributed to the contractor. Government share proportion, which is the proportion the government share to the sum of government share, and contractor share was also used in the analysis. In this case, government share proportion is $100 \%$ minus contractor share proportion.

These variables were used as dependent variables in order to see if there was a significant relationship between them and independent variables such as "the generation" of the PSCs, the region where the operators are doing their exploration, the working area (onshore or offshore), the international oil price, the size and owner of the operators to see if there is (are) significant relationship(s) between them (Size category uses the level of exploration, development, and production expenditure, while ownership refers to the majority interest held by shareholders in the home country). In addition, the possibility of that changes in the PSCs terms and conditions have influenced the level of government share and contractor share was also investigated. For the purposes of this analysis, financial data were provided by the Bureau of Finance and Economic of Pertamina MPS. These data regarding the financial performance of each of the producing Contractors covered a period 1967 to 1999. One potential weakness of this study is that these data were supplied by an official source rather than an independent one and as such, the validity and reliability of the data could be called into question. However, this is the only source of data available for the researcher or for other institutions interested in conducting research on the Indonesian PSCs. 


\section{Operational Indicators}

To investigate how changes in the PSCs terms and conditions have influenced the Indonesian up-stream activities, some operational indicators were selected. They include the length of seismic achievements, exploration wells completed, total reserves secured, total crude production and total units of PSCs signed by the government. As pointed out by Mahmud (1997), these operational indicators are believed to be closely related. For example, increased seismic activities permit the identification of more potential structures, which involves more exploration activities in order to discover deposits. This, in turn, is reflected by more exploration wells completed. In other words, one could fairly expect more petroleum reserves as a result of more exploration activities. In addition, production is also expected to increase if more reserves are found. Finally, total PSCs approved and signed by the Indonesian government could arguably be used to assess the attractiveness of the up-stream sector.

As with the financial indicators, data related to these operational indicators were also provided by the Bureau of Finance and Economic of Pertamina MPS. Unfortunately, the data available for analyzing the operational performance consisted of total annual data for all producing Contractors, which covered a period from 1967 to 1999. Therefore, the analysis was based on the aggregate data number for all Contractors rather than on individual data for a specific year. This could be another weakness of this study in addition to the fact that all data come from official resources rather than independent source.

\section{The Statistical Techniques Used to Analyze the Data}

\section{General Linear Model (GLM)}

GLM is generally used to identify how some independent variables may have significantly influenced other dependent variables using a certain confidence level. In this study, a GLM was estimated to see if independent variables such as (1) generation of the PSCs; (2)regions; (3)working areas; (4) international oil price; (5) size of the companies and (6) ownership of the companies had a significant influence on government share, contractor profits and cost recoveries.

\section{One-Way Analysis of Variance (ANOVA)}

As mentioned in the preceding sections, the terms and conditions of the Indonesian PSCs have evolved over three generations: Generation 1 (1966-1977), Generation 2 (1978-1987) and Generation 3 (1988 - 1999). These changes were believed to have come about as the result of both national and international influences (Barrow, 1993; Mahmud, 1997; Bindemann, 1999). One-way ANOVA was used to make inferences about the means of selected indicators of the PSCs at a 5\% level of significance. The test was intended to assess whether the means of each selected indicator for the three generations were equal. This test will hopefully shed some light on the effects of the changes in the PSC terms to the up-stream sector performance (Kruskal Wallis one-way ANOVA test was used as an alternative to simple factorial experiment).

\section{Multiple Comparison Tests}

Multiple comparison tests (Scheffe method) with significance at 5\% level were used to identify and analyze statistically significant relations among period means for each selected indicators and 
selected periods (The Scheffe method was used because it is the most conservative one (Ryan and Joiner, 1994).

\section{Statistical Results: Financial Indicators}

\section{Government Share}

Table 1 reveals the results from a GLM, which was estimated to investigate whether certain factors have influenced the government share over the last 30 years. Regions where explorations have taken place, working areas (onshore versus offshore), international oil price, size of the companies, and ownership of the oil companies appear to significantly influence the total government share, as indicated by p-values of less than 0.05. Quite surprisingly, however, the different PSCs generations do not seem to have significantly influenced the total government share, as indicated by a p-value larger than 0.05 (However, using one-way ANOVA, however, PSCs generation appear to have a significant influence on the level of government share, as indicated by a p-value of less than 0.05). In other words, changes in PSC terms, if combined with other independent factors do not seem to have significantly affected the government share. The Rsquared of 0.491 disclosed in the table means that all six independent variables can explain $49.1 \%$ of the variability in the government share. This result is a good indication of a strong relationship according to Ryan and Joiner (1994).

Table 1 GLM ANOVA for Government Share

\begin{tabular}{ccccccc}
\hline \multicolumn{7}{c}{ Analysis of Variance for Government Share, using Adjusted SS for Tests } \\
\hline Source & DF & Seq SS & Adj SS & Adj MS & F & P \\
\hline Region & 9 & 11.36487 & 3.33312 & 0.37035 & 13.03 & 0.000 \\
Generation & 2 & 1.70380 & 0.12627 & 0.06313 & 2.22 & 0.109 \\
Wrk.Areas & 1 & 0.20883 & 0.11817 & 0.11817 & 4.16 & 0.042 \\
Size & 2 & 1.06029 & 1.24610 & 0.62305 & 21.91 & 0.000 \\
Oilprice & 1 & 0.65020 & 0.66900 & 0.66900 & 23.53 & 0.000 \\
Ownership & 4 & 3.33518 & 3.33518 & 0.83380 & 29.33 & 0.000 \\
\hline \multicolumn{7}{c}{ R-squared = .491 (Adjusted R Squared =.474) } \\
\hline
\end{tabular}

Table 2 presents both the government share and contractor share during the three generations of PSCs.

Table 2 Means for Government and Contractor Share

\begin{tabular}{ccccc}
\hline Generation & $\begin{array}{c}\text { Government Share } \\
(\%)\end{array}$ & Rank & $\begin{array}{c}\text { Contractor } \\
\text { Share (\%) }\end{array}$ & Rank \\
\hline 1 & 0.4486 & 2 & 0.5514 & 2 \\
\hline 2 & 0.5749 & 1 & 0.4251 & 3 \\
\hline 3 & 0.4240 & 3 & 0.576 & 1 \\
\hline
\end{tabular}


From the table it can be seen that there was an increase in the government share in PSCs generation 1 from 44,9 per cent to 57.5 per cent in PSC generation 2. However, in PSCs generation 3 government share decreased to 42.4 per cent. The main message here is that changes in PSCs over three generations have had a tendency to benefit more the Contractors than the host government. This phenomenon can be clearly seen in from Figure 1 which shows that the government share, particularly since 1981, has tended to decrease, despite the high international price, while the contractor share has tended to increase.

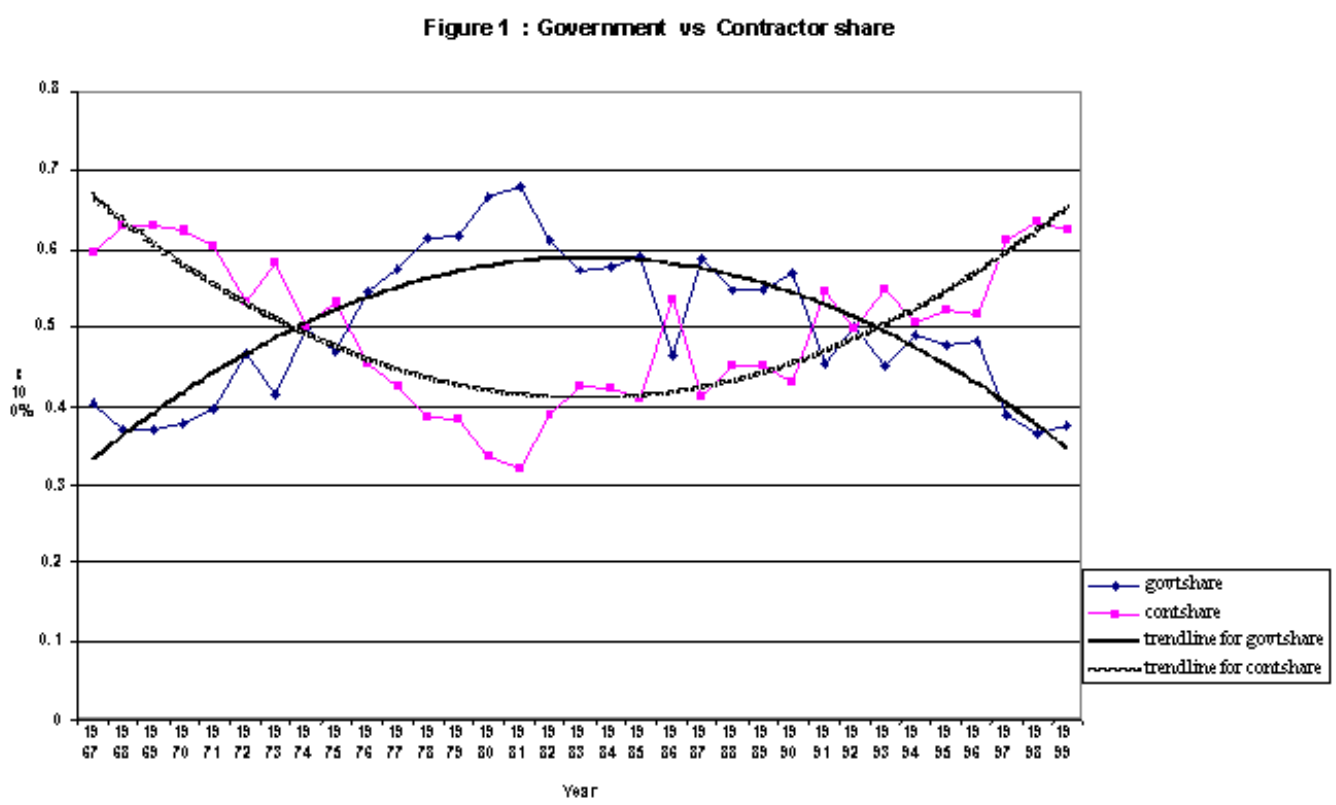

As far as the oil producing regions are concerned, Table 3 reveals that, over the last 30 years, the Contractors operating in Central Sumatera are those that have contributed the highest revenue proportion for the government (64.72\%), followed by those in Irian Jaya (54.98\%), Western Java (51.68\%), and Eastern Kalimantan (51.12\%).

Table 3 Government Share by Regions

\begin{tabular}{lccrc}
\hline \multicolumn{1}{c}{ Regions } & $\begin{array}{c}\text { Governmet } \\
\text { share (\%) }\end{array}$ & Rank & $\begin{array}{c}\text { Government share (in } \\
\text { US\$ 000) }\end{array}$ & Rank \\
\hline Central Sumatera (Riau) & 0.647 & 1 & $772,767.00$ & 1 \\
\hline Eastern Java & 0.093 & 9 & $14,982.00$ & 7 \\
\hline Eastern Kalimantan & 0.511 & 4 & $298,103.00$ & 4 \\
\hline Irian Jaya & 0.550 & 2 & $125,574.00$ & 5 \\
\hline Jambi & 0.097 & 8 & $5,656.00$ & 8 \\
\hline Maluku & 0.188 & 7 & $1,441.00$ & 9 \\
\hline Northern Sumatera (Aceh) & 0.437 & 5 & $378,220.00$ & 3 \\
\hline Southern Sulawesi & 0.409 & 6 & $117,289.00$ & 6 \\
\hline Southern Sumatera & 0.035 & 10 & $500,714.00$ & 2 \\
\hline Western Java & 0.517 & 3 & & 10 \\
\hline
\end{tabular}


Working areas of the FOCs appear to have significantly influenced the amount of oil revenue contributed to the government, as indicated by a p-value of 0.043 at a $5 \%$ confidence level. Table 4 presents the proportion of total revenue transferred to the government based on the working area of the Contractors.

Table 4 Government Share by Working Areas

\begin{tabular}{lcccc}
\hline Working Area & $\begin{array}{c}\text { Government Share } \\
(\%)\end{array}$ & Rank & $\begin{array}{c}\text { Government Share } \\
\text { (in US\$ 000) }\end{array}$ & Rank \\
\hline Onshore areas & 0.467 & 2 & 349,307 & 1 \\
\hline Offshore areas & 0.488 & 1 & 333,648 & 2 \\
\hline
\end{tabular}

Contractors operating in offshore areas seem to have contributed more revenues to the government than those in onshore areas over the last 30 years (48.8\% versus $46.7 \%$ ). In PSCs generation 1, companies operating onshore have contributed US\$191,331,000 on average to the government; this is more than 200 times greater than that contributed by those operating offshore, with a mean US\$ 93,057,000. However, in PSCs generation 2, those operating offshore have contributed the most with a mean of US\$534,356,000 (see table 2, Appendix 2).

Table 5 reveals that large Contractors have contributed the most total revenue for the government. Large companies have supplied more than $50 \%$ of their total revenues, while medium and small companies have contributed less than 50\%. Given that a high proportion of government revenue comes from large companies, it is quite understandable if large companies have a strong bargaining position in influencing government policy of the industry.

Table 5 Government Share by Size of the Operator

\begin{tabular}{lccrc}
\hline \multicolumn{1}{c}{ Size of the Operator } & $\begin{array}{c}\text { Government } \\
\text { Share (\%) }\end{array}$ & Rank & $\begin{array}{c}\text { Government Share } \\
\text { (in US\$ 000) }\end{array}$ & Rank \\
\hline Small & 0.182 & 3 & 1,211 & 3 \\
\hline Medium & 0.441 & 2 & 136,524 & 2 \\
\hline Large & 0.541 & 1 & 522,097 & 1 \\
\hline
\end{tabular}

\section{Contractor Profit}

Table 6 presents means for total contractor profits based on the 'generations' of the PSCs, the regions, the working areas, the size and the ownership of the FOCs over the last 30 years.

Table 6 Means for Contractor Profit

\begin{tabular}{ccc}
\hline Category & US \$ 000 & Rank \\
\hline Generation & & \\
\hline 1 & 58,267 & 3 \\
\hline
\end{tabular}


Table 6 Means for Contractor Profit (continued)

\begin{tabular}{|c|c|c|}
\hline 2 & 99,012 & 1 \\
\hline 3 & 63,861 & 2 \\
\hline \multicolumn{3}{|l|}{ Regions } \\
\hline Central Sumatera (Riau) & 123,462 & 2 \\
\hline Eastern Java & 6,782 & 7 \\
\hline Eastern Kalimantan & 82,383 & 3 \\
\hline Irian Jaya & 15,391 & 6 \\
\hline Jambi & 2,181 & 8 \\
\hline Maluku & 239 & 10 \\
\hline Northern Sumatera (Aceh) & 172,866 & 1 \\
\hline Southern Sulawesi & 1,239 & 9 \\
\hline Southern Sumatera & 19,590 & 5 \\
\hline Western Java & 81,153 & 4 \\
\hline \multicolumn{3}{|l|}{ Working areas } \\
\hline Onshore areas & 82,241 & 1 \\
\hline Offshore areas & 59,023 & 2 \\
\hline \multicolumn{3}{|c|}{ Size of the Operator } \\
\hline Small & 387 & 3 \\
\hline Medium & 27,067 & 2 \\
\hline Large & 111,623 & 1 \\
\hline \multicolumn{3}{|l|}{ Ownership } \\
\hline US & 130,913 & 1 \\
\hline UK & 55,712 & 3 \\
\hline France & 85,470 & 2 \\
\hline Canada & 6,137 & 5 \\
\hline Others & 20,691 & 4 \\
\hline
\end{tabular}

From the table it can be seen that there was an increase in Contractors' profits from a mean US\$ 58,267,000 in PSCs generation 1 to US\$ 99,012,000 in generation 2, which represents an increase of $41.15 \%$. However, in PSCs generation 3 contractor profits decreased $35.5 \%$ to only US\$ 63,861,000.

\section{Operational Indicators}

Table 7 illustrates how the operational activities of the petroleum industry have developed over the last 30 year. In particular, the table details indicators such as the length of the seismic achievement, total exploratory wells, total oil reserves, total crude oil production and the total unit of contract signed between the host government and the FOCs. 
Table 7 ANOVA FOR PSCs Operational Indicators (1967-1999)

\begin{tabular}{|c|c|c|c|c|c|c|c|c|c|}
\hline \multirow[t]{3}{*}{$\begin{array}{c}\text { Selected } \\
\text { Indicators }\end{array}$} & \multicolumn{3}{|c|}{ One-Way ANOVA } & \multicolumn{3}{|c|}{ Kruskal Wallis } & \multicolumn{2}{|c|}{$\begin{array}{c}\text { Test of } \\
\text { Significance at } 5 \% \\
\text { level }\end{array}$} & $\begin{array}{c}\text { Multiple range test } \\
\text { (Scheffe method) } \\
\text { at 5\% level }\end{array}$ \\
\hline & \multicolumn{3}{|c|}{ Period Means } & \multicolumn{3}{|c|}{ Period Means } & & & \\
\hline & Gen.1 & Gen.2 & Gen.3 & Gen.1 & Gen.2 & Gen.3 & ANOVA & KW & \\
\hline Seismic & 38,979 & 45,528 & 136,494 & 42,058 & 42,459 & 75,565 & 0.01 & 0.00 & $\begin{array}{l}\text { Gen } 3>\text { Gen 1; } \\
\text { Gen } 3>\text { Gen } 2\end{array}$ \\
\hline $\begin{array}{c}\text { Exploratory } \\
\text { Wells } \\
\end{array}$ & 119.70 & 183.55 & 127.42 & 142 & 185 & 124.50 & 0.01 & 0.03 & $\begin{array}{l}\text { Gen2> } \\
\text { Gen3>Gen1 }\end{array}$ \\
\hline Reserve & 3,186 & 7,038 & 10,091 & 3,156 & 7,850 & 10,066 & 0.00 & 0.00 & $\begin{array}{l}\text { Gen2> } \\
\text { Gen3>Gen1 }\end{array}$ \\
\hline $\begin{array}{l}\text { Crude oil } \\
\text { production }\end{array}$ & 971 & 1,491 & 1,531 & 890 & 1,415 & 1,568 & 0.00 & 0.00 & $\begin{array}{l}\text { Gen 3> Gen1; } \\
\text { Gen 2> Gen1 }\end{array}$ \\
\hline $\begin{array}{c}\text { Unit of } \\
\text { contract }\end{array}$ & 6.22 & 9.27 & 13.33 & 5.00 & 9.00 & 14.50 & 0.00 & 0.01 & $\begin{array}{l}\text { Gen 3>Gen1; } \\
\text { Gen3>Gen2 }\end{array}$ \\
\hline
\end{tabular}

\section{Discussion of Results and Linkage to Concept of Accountability}

\section{Contractor Share Increases at the Expense of Government Share?}

As discussed previously, in the PSCs generation 1 (1967-1976) the average government share was $44.86 \%$, while for generation 2 (1978-1987), it was $57.49 \%$ and for generation 3 (19881999), it was $42.40 \%$. Quite surprisingly in 22 of 33 years, the host government proportion of the petroleum revenue was less than $50 \%$. By contrast, for the majority of this period the contractor share, consisting of profit and cost recoveries was, more than $50 \%$. The highest government share was $68 \%$ in 1981, while the lowest share was only $36.5 \%$ in 1998.

As has been previously discussed, the government share since 1981 has declined while the contractor share has increased. For a while, changes in the terms and conditions of the PSCs in the second generation has increased the government share. Unfortunately, the increase did not last long enough. The trend line of government share in the figure indicates that from 1981 onwards, despite high international oil prices, the government share has decreased. The high international oil price since 1974 seems to have actually brought more benefits to the FOCs than to the host government. A series of exploration incentive packages introduced by the government at the beginning of the 1990s to attract more investment in the petroleum sector appears to have been unsuccessful in increasing the government share. Indeed, the incentive packages have increased the contractor share. However, an increase in contractor share seems to have been at the expense of a decrease in government share.

The introduction of a new scheme for calculating cost recoveries in 1977 to replace the $40 \%$ cap in cost recoveries and the apparent weakness of government control on the implementation, seem to have caused a loss of government portion (Sihotang, 2003). One argument is that this new cost recovery scheme has presented a number of loopholes that can be exploited by Contractors to inflate their cost (recoveries) which eventually causes huge inefficiency to the industry. Furthermore, the changes in the content of the PSCs do not seem to have added value to the petroleum industry since the current structure of managing the petroleum industry-with the NOC (now BP) as manager and FOCs only as contractor to NOC (now BP) does not have enough capability and competence for effective control. In this respect, one could 
argue that, in order for the changes in the content of the PSCs between the host country and FOCs to add value to the industry, the current accountability relationship between them needs to be properly re-structured (see also Laughlin, 1990 and 1996). PSCs as tool for implementing contractual accountability relationship between host country as principal and FOCs as agents has to provide structure that can balance the principal' unquestioned right to control the behaviour of the agent' (Laughlin, 1996) and the agent's freedom to pursue whatever actions that seem appropriate (Stewart, 1984).

The changes in terms and conditions of PSCs over their three generations seem to be unable to eliminate the unbalance revenue share between the host country and FOCs. This could be as a result of the PSC emphasis on probity accountability base of Stewart (1984), which focuses too much on legal meaning of the contract. PSCs' changes in terms and conditions over the last 30 appear to lack capability to provide industry mechanism and practices to achieve performance and policy accountability bases in Indonesian petroleum industry (Stewart, 1984) (More about accountability issues could be found in Stewart (1984) and Laughlin (1996)). As a result, the whole accountability relationship between the host country and FOCs seem to have failed in adding value in the Indonesian petroleum industry for equal benefits of both host county and FOCs. In addition, the notion of low trust in the accountability relationship in Indonesian petroleum industry may lead the host country to exert greater control over the behaviour of the agent through more formal and sophisticated systems and procedures (Fox, 1974; Laughlin, 1996).

In comparison to a previous study by Bindenman (1999) on PSCs economic performance over the period 1966 to 1998, the government share contributed from the Indonesian PSCs is actually below both regional and worldwide averages. For example, in Asia, the average government share ranges from a minimum of $55.85 \%$ to a maximum of $71.79 \%$ (In her study, she reported the contractor share rather than the government share. Indeed, the government share is $100 \%$ minus the contractor share. She also reported contractor share in other regions such as in Central America (36.57\% to 64.71\%), Eastern Europe (37\% to 51.93\%), Middle East (15.75\% to $27.80 \%$ ), in North Africa (18\% to 38.67\%) and South Central Africa (29.17\% to 55.69\%)). While Indonesian PSCs range from a minimum of $36.5 \%$ to a maximum of $68 \%$. Bindeman (1999) argued that one possible explanation for a low government share is the FOCs' operating inefficiency caused by a lack of effective industry infrastructure, such as a lack of reliable host country control mechanisms and a lack of best practice guidelines in all aspects of the industry's activities.

It is clear from this argument that the government's structure and strategy for managing the industry needs to be urgently reformed in order to find ways to add more efficiency to the industry. Government management control of the industry needs to focus more on operational efficiency issues rather than on narrow financial compliance. In order to add more efficiency to the industry, not only does there have to be a strong government control in place, but also industry best practice guidelines and indicators need to be introduced and developed.

The trendline for the contractor's net profit and cost recoveries over the last 30 years indicated that the average cost recoveries were higher than that of contractor profit, especially since 1977 when a new cost recovery scheme was introduced. It seems there are at least three possible explanations for this. First, the contractor possibly expanded their exploration and development in such frontier areas as deepwater offshore that requires very intensive capital. Second, the contractor's operations are possibly not efficient. Third, there could be a combination of the two. One can argue that third reason could be most plausible since the average cost recovery 
and exploration cost per barrel of crude oil has been increasing over the last 30 years. This should not have been the case if contractors' operations, as a result of their long learning curve, were efficient. Even worse, the government supervisory and control ability has been so ineffective and incapable of doing the proper job to manage the FOCs' operations (Oon, 1986). According to Oon:

"There may indeed be a trend towards an apparent new accommodation between the foreign company and host government, but this does not mean that the latter has necessarily secured a markedly greater share of the benefits from the extractive operation. Preoccupation with obtaining formal ownership and control over the extractive operation has not meant that real control has in fact been exercised" (p.220)

Once again, the issues of industry best practice and strong government control are central if the petroleum industry is to operate efficiently for the benefit of both the host government and the FOCs. This issue of oil industry best practice was also raised by Bindenman (1999) when she pointed out:

"The host government's main concern in the context of uncertain exploration and development is that FOC applies best-practice methods during both stages in order to maximize total production. And they [host government] can ensure this by having the capability for monitoring the operation...” (p.86).

\section{Role for Local Authorities and People}

The longitudinal analysis on the petroleum industry performance for the last 30 indicates that there have been only four regions that have contributed the majority of oil revenue to the host government. They include Central Sumatera, West Java, Northern Sumatera and Eastern Kalimantan. Yet, for the last 30 years, the central government has ignored the interests and aspirations of these regional governments and their local people. As a result, all of these regions are now desperately asking for the right to get involved in managing the petroleum industry through a variety of mechanisms. Northern Sumatera, especially in the Aceh sub-region, has been the most troubled area. Trouble in this area has prevented the FOCs from operating its main gas fields for more than one year in 2001 that have caused million losses both for the government and the contractor (Financial Times, 2001).

As argued by Bennet and Sellgren (1992) the vertical transfer of central government authority to the local authority (Also known as decentralization) in managing strategic natural resources such as oil and gas will open the way for local people get involved in the monitoring and control functions of the natural resources. In the context of developing countries, they further argued that failure to accommodate the interests of the local authority and its people in the decision-making structure could cause social unrest that will create inefficiency in the industry.

Similarly, Korten (1995) argued that the local community has to be empowered to create localized economies. In this sense, he further argued that the system of global co-operation has to be transformed to empower the local since:

“development depends on the people's ability to gain control and use effectively the real resources of their localities...Yet most development interventions transfer control of local resources to even larger and more 
centralized institutions that are unaccountable to local people and unresponsive to their needs “(p.5).

In fact, since 1998 there have been enormous efforts by the Indonesian central government to proactively respond to the aspirations of the local people and authority. These efforts culminated in 1999 when the Parliament passed two laws, which were intended to empower the role of the local governments in Indonesia. These two laws consist of Law No.22/1999 regarding the 'Regional Government Autonomy'; and Law No.23/1999 regarding the 'Balance Budget for Central Government and Regional Government'. Law No.22/1999 states that the regional governments have the power to manage all natural resources in the regions, except oil and gas. In other words, managing the petroleum industry is still under central government authority. There is speculation that the exclusion of the regional government from managing oil and gas activities management is due to the intensive lobbying by the major FOCs who see that the active role of the regional government in managing the petroleum industry will do more harm than good (The Jakarta Post, 2001). Indeed, Law No.23/1999 states that the regional government will get $15 \%$ of the total petroleum revenue resulting from the region after the Contractor takes its share. However, the regional governments also claim that their voices need to be heard and their interests need to be accommodated in petroleum management. This phenomenon adds credibility to the introduction of a new structure of accountability relationship between the host governments (central and regional governments) and the FOCs.

\section{Dominant Role for Foreign Influence}

US, UK, and French oil companies have been the largest revenue contributors to government coffers over the last 30 years, with those from the US being the largest. One can argue that these foreign companies will also bring with them their own self-interest agenda to influence the way a country like Indonesia manages the industry (Ikenberrry and Kupchan, 1990).

This phenomenon was also supported when looking at comments of some local experts during the discussion of a new oil and gas law in Indonesia when they suspected that "this new oil and gas law is actually for the benefit of foreign interests" (Jakarta Post, 2001). Under the new law, the role of petroleum management has transferred from Pertamina to the government. Although this is intended to increase industry efficiency by abolishing the dual conflicting role of the NOC, it could potentially do more harm than good for the future of the industry in Indonesia if the government lets itself be guided by these foreign interests (Mikesell, 1971; Mackay and Mackay, 1975). Moreover, it is going to be very difficult for the government to keep free from the influence of foreign interests in managing the industry, given that $90 \%$ of Indonesian petroleum working areas are controlled by foreign operators, and that FOCs produce in excess of $95 \%$ of the country's oil and gas (Pane, 2000; Machmud, 2000), Therefore, government regulation of the industry needs to be strengthened by introducing industry best practices in all important areas (Noreng, 1980). In this way, foreign interests may be neutralized (Aharoni, 1986; Oon, 1986).

Given foreign companies have dominated the Indonesian petroleum industry for the last 30 years, it may well be that any industry best practices that is introduced will be influenced heavily by the practices of those companies. However, evidence revealed from studies by Hove (1986) and Parera (1989) should be borne in mind; they claimed that the exploitative and colonizing tendency of developed countries might be seen in the name of harmonization and standardization of international standards and practices through the dominant role of multinational corporations. For example, accounting and reporting standards and practices implemented in 
developed countries have been imposed on the developing countries without the consideration of local interests (Hove, 1996).

In this context, Briston (1984) pointed out that developing countries are really in need of industry best practices, especially in accounting and auditing, that enables them to control the multinational corporations and help them in economic planning and decision-making. For example, these accounting practices will not only capture the financial aspect of the foreign company's operation but also the non-financial aspect such as information regarding the purchase of inputs locally, profit and capital repatriations, extent of planned or actual local equity participation, the level of employment provided, environmental protection, construction of social overheads such as roads and housing, and the use of locally owned transportation. It is this nonfinancial aspect that PSCs have failed to capture over their three generations.

\section{CONCLUSION}

The longitudinal study on the PSCs performance over the last 30 years have indicated that the current structure of the agreements seemed to have failed in supporting the dynamic contractual accountability between the host country and the FOCs. The PSCs lacked the capability to promote both host country and FOCs' interests in a fair and reasonable way. Changes in terms and conditions of the Indonesian PSCs without changes in accountability structure seemed to have led to positive changes in the up-stream sector's operational performance; However, this increase in industry performance appears to have benefited FOCs at the expense of the host country due to the latter's lack of capability for controlling the behaviour of the former.

Indeed, changes in PSCs terms and conditions over the last 30 years have done more harm than good for developing an accountable and transparent government-led management of the Indonesian petroleum industry. Findings from the longitudinal study seem to confirm (1) the need for the restructuring of the current accountability relationship between the host country and FOCs followed by changes in terms and conditions of the current PSCs; and (2) the need for introducing industry best practice to facilitate the restructured accountability relationship in order to add more value in the industry for the equal benefit of the host country and FOCs.

\section{REFERENCES}

Aharoni, Yair. 1986. The Evolution and Management of State Owned Enterprises. Cambridge, MA.: Ballinger Publishing.

Anoymous. 2001b. "Liberalising the Oil Industry," Jakarta Post. October 25 ${ }^{\text {th }}$. (www.thejakartapost.com)

. 2001b. "Jakarta Aims to Liberalise Oil and Gas Sector," Financial Times Limited, URL:http://news.ft.com, 24.10.2001.

Barnes, Philip. 1995. Indonesia: The Political Economy and Energy. Oxford: Oxford University 
Press for the Oxford Institute for Energy Studies.

Barrows, Gordon. 1993. Production Sharing in Indonesia, 1966 to 1993: Evolution and Trends. Houston: Institute for International Research.

Bee, O.J. 1982. The Petroleum Resources of Indonesia. Kuala Lumpur: Oxford University Press.

Bennett, R. and J. Sellgren. 1992. "The Role of Local Government in Economic Development," in King, D (eds), Local Government Economics in Theory and Practice. London: Routledge.

Bindemann, Kirsten. 1999. Production Sharing Agreements: An Economic Analysis. Oxford: Oxford Institute for Energy Studies.

Briston, R.J. 1984. “Accounting Standards and Host Country Control of Multinationals,” British Accounting Review. 16(10), Spring, pp 12-26.

Fox, A.1974. Beyond Contract: Work, Power, and Trust Relations. London: Faber.

Hove, M.R. 1986. "Accounting Practices in Developing Countries: Colonialism's Legacy of Inappropriate Technologies," Journal of International Accounting. 22, Fall, pp. 81-100.

Ikenberrry, J. and Kupchan, C. 1990. "Socialization and Hegemonic Power," International Organization. Vol.44. No.3. Summer, p.3.

Johnston, D. 1994b. "International Petroleum Fiscal Systems: Production Sharing Contracts," Petroleum Accounting and Financial Management. Vol.13, No.2, pp. 24-75.

Korten, D.C. 1995. When Corporations Rule the World. London: Earthscan.

Laughlin, R. 1996. "Principals and Higher Principals: Accounting for Accountability in the Caring professions," in Munro, R. and Mouritsen, J. (eds) Accountability: Power, Ethos, and The Technologies of Managing. International Thomson Business Press.

Machmud, Tengku N. 2000. The Indonesian Production Sharing Contract: An Inverstor's Perspective. The Hague: Klulwer.

Mahmud, Mustafa B. 1997. "Accounting and the Economic Development of the Oil and Gas Sector in Libya: Historical Review, Theoretical Analysis and Empirical Investigation,” Unpublished PhD Thesis, University of Dundee.

Mikesell, Raymond F. 1971. Foreign Investment in the Petroleum and Mineral Industries: Case Studies of Investor-Host Country Relations. Baltimore: Johns Hopkins Press for Resources for the Future.

MacKay and Mackay. 1975. The Political Economy of North Sea Oil. London: Martin Robertson.

Oon, K.C. 1986. The politics of Oil in Indonesia: Foreign Company - Host Government Relations. Cambridge: Cambridge University Press. 
Pane, S.Z. 2001. "Pertamina, Expanding The Global E and P Reach.” Unpublished paper, 6 ${ }^{\text {th }}$ Annual Third Millennium Petroleum 2001, Global Pacific \& Partners, May 2001.

Parera, M.H.B. 1989. "Accounting in Developing Countries: A Case of localised uniformity," British Accounting Review. 21(2), pp 141.

Rochmat, Rudioro. 1981. Contractual Arrangements in Oil and Gas Mining Enterprises in Indonesia. Sijthoff \& Noordhoff, The Netherlands.

Ryan, B.F. and Joiner B.L. 1994. MINITAB Handbook. Duxbury Press.

Sihotang P. and Russell A. 2001b. "New Oil and Gas Law: Threat to Government?” The Jakarta Post, October 29.

Stewart, J. 1984. "The Role of Information in Public Accountability," in Hopwood, A and Tomkins, C (eds) Issues in Public Sector Accounting. Oxford: Philip Allen. 